\title{
COVID-19 coronavirus: pathogenesis, clinical features, diagnostics, epidemiology, prevention and control
}

\section{El-Maradny $\mathbf{Y A}^{1,2}$, Othman $\mathrm{AM}^{3}$, Gerges $\mathbf{M M}^{3}$, Belal $\mathbf{F H}^{4}$, Behery $\mathbf{E A}^{4}$ and El- Fakharany $\mathbf{E M}^{1^{*}}$}

${ }^{1}$ Protein Research Department, Genetic Engineering and Biotechnology Research Institute, City of Scientific Research and Technological Applications (SRTA-City), New Borg EL-Arab, Alexandria, Egypt.

${ }^{2}$ Microbiology Department, High Institute of Public Health, Alexandria University, Alexandria, Egypt.

${ }^{3}$ Faculty of pharmacy and drug manufacturing, Pharos University, Alexandria, Egypt.

${ }^{4}$ Biotechnology Department, Institute of Graduate studies and Research, Alexandria, Egypt.

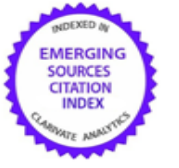

\section{ARTICLE INFO \\ Article history \\ Received 21 June 2020 \\ Received revised 25 June 2020 \\ Accepted 27 June 2020 \\ Available online 30 June 2020 \\ (C) El-Mardany et al. 2020 \\ Corresponding Editor: \\ Darwish AG, Balbool BA}

\section{Keywords}

SARS-CoV

MERS-CoV

MERS-CoV-2

COVID-19

\begin{abstract}
Spreading of the diseases from country to country and from continent to another is one of the drawbacks of globalization. In December 2019, from Wuhan in China, COVID-19 was emerged as a new viral disease caused by a novel betacoronavirus which spread in more than 210 countries and 3 continents over 3 months. "SARSCoV-2" is the name of the virus while "Coronavirus Disease 2019" (COVID-19) is the disease itself. Coronaviruses cause a variety of diseases in birds and mammals ranging from mild upper respiratory disease to severe acute respiratory distress which may lead to death. The aim of this review is to provide a brief introduction to coronaviruses, demonstrate and describe clinical features, epidemiological, transmission mode, treatment and vaccination trials of COVID-19 globally and in Egypt, and an attempt to review the rapid identification and diagnostic features of this virus as well as summarize history of pandemic and epidemic viral diseases. We hope our review will provide the global community and the literature with the wise steps for controlling and preventing the outbreak of this severe pathogenic virus.
\end{abstract}

Published by Arab Society for Fungal Conservation

\section{Introduction}

Coronaviruses are belonging to the subfamily Coronavirinae, family Coronaviridae, order Nidovirales.

They are enveloped viruses with a single stranded positive-sense RNA. The name of corona means crown in which a characteristic club-like spikes project from surface of the virus, an unusually large RNA genome, and a unique replication strategy. Coronaviruses are divided into four genotypes (alpha, beta, gamma and delta), alpha and beta are pathogenic to humans, with twenty-six different species featured by various antigenic crossreactivity (Cleri et al. 2010; de Wilde et al. 2017). Coronaviruses have long been categorized as imperative veterinary viral pathogens, affecting numerous species of

\footnotetext{
* Corresponding author

E-mail address: esmailelfakharany@yahoo.co.uk (El-Fakharany EM)
}

mammals and birds causing respiratory and enteric diseases. However, coronaviruses have been infecting humans for at least 500-800 years, and all are suggested to be originated in bats (Berry et al. 2015).

The first isolated coronavirus was the avian infection in 1937, which cause of devastating infections in chicken. After that, the first human coronavirus (HCoVs) was isolated in 1965 from infected patient and propagated in vitro by (Tyrrell et al. 1965) using human ciliated embryonic trachea cell line. HCoVs including $\mathrm{HCoV}$ 229E, OC43, NL63, and HKU1, cause mild respiratory diseases and have been considered negligible viral pathogens in healthy people.

In the $21^{\text {st }}$ century, severe acute respiratory syndrome coronavirus (SARS-CoV) and middle east respiratory 
syndrome coronavirus (MERS-CoV) as two highly pathogenic strains of $\mathrm{HCoVs}$, caused severe illness, the mortality rates were $10 \%$ and $37 \%$, respectively, and more than 10,000 cumulative cases (Ksiazek et al. 2013).

In December 2019, another novel pathogenic strain of $\mathrm{HCoVs}$ was discovered throughout a suspicious incidence of pneumonia in a Chinese city called Wuhan and has caused serious illness and death. SARS-CoV-2 is characterized by high transmission efficiency, and a rapidly increasing incidence of infections (Zhao et al. 2020) and its possibility of transmission by asymptomatic carriers (Biscayart et al. 2020). On 30 January 2020, the World Health Organization (WHO) declared the COVID19 outbreak as the sixth public health emergency of international concern, following H1N1 (2009), polio (2014), Ebola in West Africa (2014), Zika (2016) and Ebola in the Democratic Republic of Congo (2019). In 11 March 2020, WHO declared COVID-19 a pandemic, when over 118,000 cases in over 110 countries around the world suffered from it. Therefore, special concern and global co-operation of the health workers, governments and public should be taken to prevent its spread.

Here we provide a brief discussion to the history of viral pandemics and coronaviruses reviewing their epidemiology and pathogenicity, and the methods of diagnosis of the highly pathogenic SARS-CoV2 (COVID-19). We will also discuss current treatment strategies, vaccination, prevention and control parameters of COVID-19.

\section{Epidemiology of COVID-19 and history of pandemics}

\section{of some viral diseases}

SARS-CoV-2 was transmitted from China then propagates through Asia and spreaded through Europe mainly by starting in Italy and a huge wildfire spreading in the world occur. The incidence rate is growing enormously, as the mortality rate of COVID-19 in Wuhan was $4.9 \%$ (WHO-China Joint Mission on COVID-19 2020). The mortality rate of COVID-19 is differing between countries and it is very difficult to calculate the fatality rate while the pandemic is still ongoing.

The basic reproduction number ( $\mathrm{R} 0, \mathrm{R}$ naught or $\mathrm{R}$ zero) is an indication of the transmissibility and the risk of a virus with respect to epidemic spread, representing the average number of new infections generated by an infectious person in a totally naïve population. WHO estimated the mean of the R0 to be 1.95, while (Liu et al. 2020) review found that the R0 average to be 3.28 which exceed WHO estimates.

The problem in this disease is that people might be confused between the COVID-19 symptoms and the influenza virus symptoms and one of the major problems also within corona species is the high genetic variation and the high modification in the viral genomic structure. At the time of this manuscript 31/5/2020, 6,234,611 confirmed cases and 373,107 deaths and 2,781,605 recovery cases of COVID-19 were reported globally, in 215 countries and territories (European Centre for Disease Prevention and Control (ECDC), 2020).

The global daily cases and deaths illustrated in figure (1) and figure (2) represents the world population with COVID-19. The highest numbers of cases were found in United States of America, Brazil and Russia. While, the highest number of deaths were found in United States of America, United Kingdom and Italy. In Egypt, the first case of COVID-19 was discovered on February 14 and reached to 24,985 total confirmed cases and 959 total deaths till 31 May 2020 (worldometers. 2020; European Centre for Disease Prevention and Control (ECDC). 2020).

According to (WHO situation report no 7. 2020), COVID-19 can infect people of all ages, ranging from 2 to 74 while the median age of cases is 45 years $71 \%$ of them were males. Ilaria Capua, a virologist and director of the One Health Center of Excellence at the University of Florida, USA, suggested that Italy has a high spread of COVID-19 because it has the highest number of deaths from antibiotic resistance in the European Union. Good differentiation should be done by pathologist to distinguish between SARS-CoV-2 as the primary pathogen or opportunistic pathogen by multidrug-resistant bacteria (Paterlini 2020). The history of viral pandemics and epidemics is shown in detail in table (1) and illustrated in figure (3) where most of the viruses causing pandemics are RNA enveloped viruses with a high mutation rate.

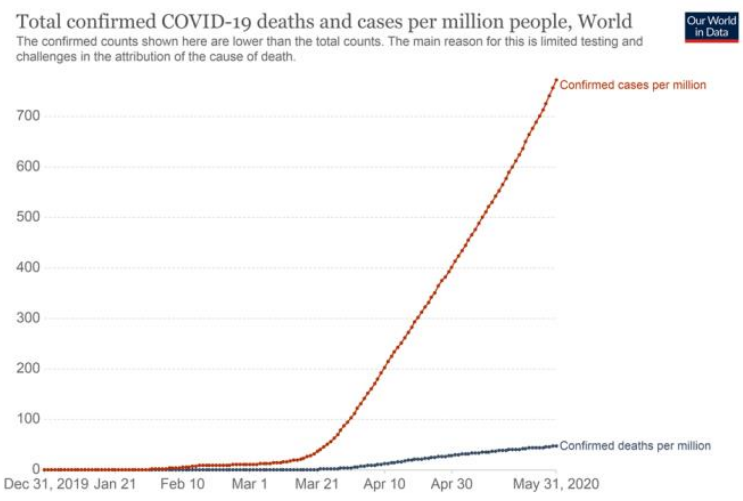

Fig 1. Global total confirmed cases and deaths due to COVID-19 (ECDC 2020).

\section{Viral structure of COVID-19}

Genetic recombination or convergent evolution events at spike protein of SARS-CoV-2 could be the reason 
causing its high transmission rate compared to SARS$\mathrm{CoV}$ (Shereen et al. 2020). The S protein of both SARSCoV-2 and SARS- CoV are similar where they are interact with human angiotensin-converting enzyme-2 (ACE2) receptor which is the reason of the human transmission, but they are differ in the salt bridge which help SARS-CoV-2 for a more efficient binding (Khalifa et al. 2020).

The spike glycoprotein of the coronavirus is responsible for the determination of the host range, tissue tropism of coronaviruses and viral entry to host cells by binding to a host receptor through its highly variable S1 subunit, then fusion to host membrane through the more conserved S2 subunit.

The $\mathrm{S} 1$ subunit is divided into $\mathrm{N}$ terminal domain (NTD) and a C terminal domain (CTD) (figure 4), in most of CoVs the NTD attached to a sugar on the cell surface of human galectins, galactose-binding lectins after structural folding, and the CTD is responsible for binding of the virus with ACE2 on host receptor (Walls et al. 2020).

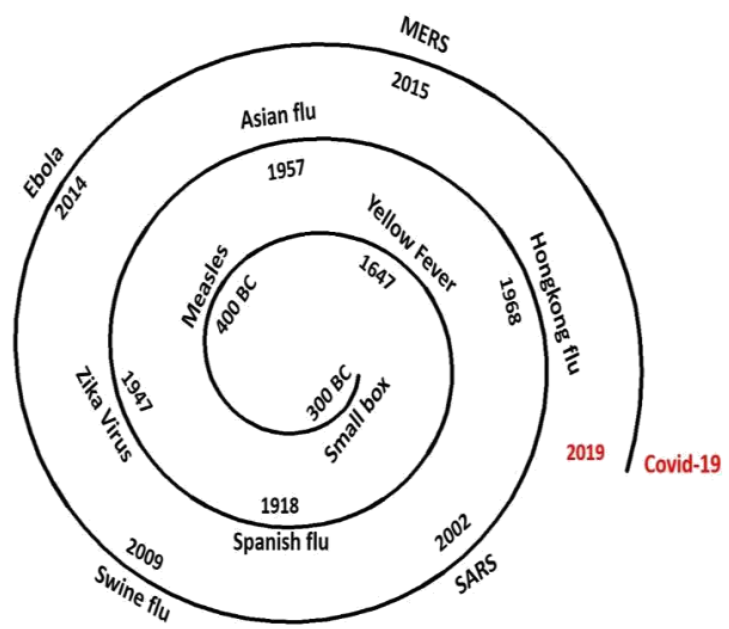

Fig 3. Illustration of the history of some viral epidemics and pandemics.

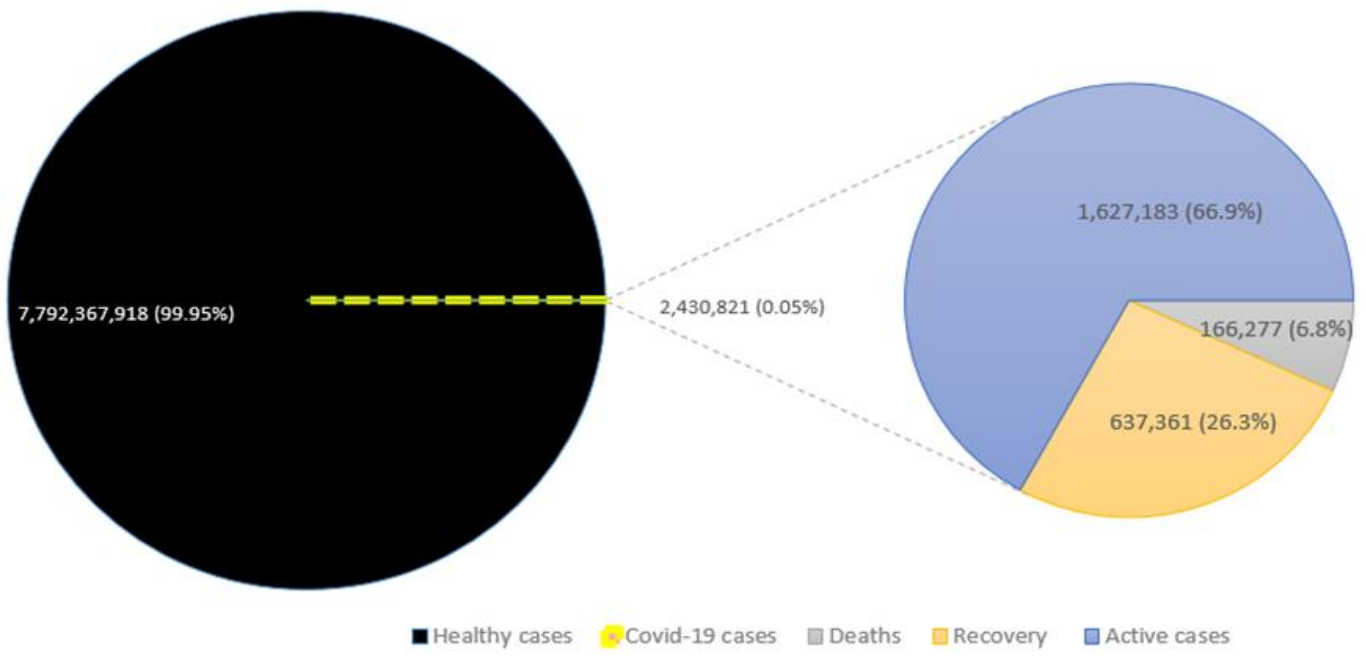

Fig 2. Pie charts represent the world population with COVID-19; A. Black area represents the healthy non infected population. B. The infected population with COVID-19 divided into active cases, recovery and deaths.

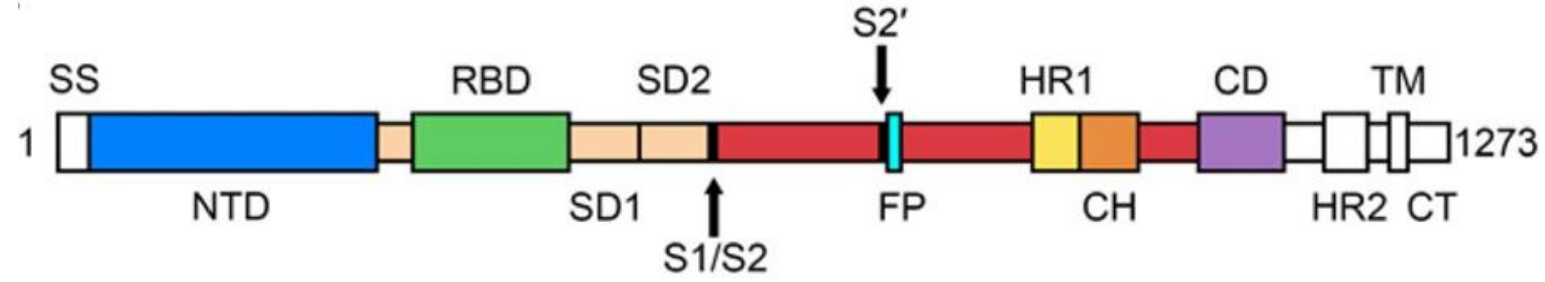

Fig 4. Schematic of 2019-nCoV S primary structure colored by domain. Domains that were excluded from the ectodomain expression construct or could not be visualized in the final map are colored white. Starting from the Nterminus domain (NTD) of S1, C-terminal domain (CTD), the S1/S2 first protease cleavage site, the fusion peptide (FP) which contains the second protease cleavage site (S2'), heptad repeat 1 (HR1), central helix (CH), connected domain (CD), heptad repeat 2 (HR2), cytoplasmic tail (CT). Protease cleavage sites represented with arrows (Wrapp et al., 2020). 
Table 1 Comparison between different viral epidemics and pandemics, where R0 equal to reproduction time

\begin{tabular}{|c|c|c|c|c|c|c|c|c|c|}
\hline Virus & Pandemics and Epidemics & Structure & R0* & Host & Symptoms & Transmission & $\begin{array}{c}\text { Treatment } \\
\text { and vaccine }\end{array}$ & $\begin{array}{l}\text { Mortality } \\
\text { rate }\end{array}$ & References \\
\hline $\begin{array}{l}\text { Smallpox } \\
\text { Variola virus }\end{array}$ & $\begin{array}{l}\text {-First outbreak in the } 3^{\text {rd }} \text { century BCE } \\
\text { (Before Common Era) } \\
\text { - Many outbreaks and on May } 8 \text {, } \\
1980 \text {, the } 33^{\text {rd }} \text { World Health Assembly } \\
\text { officially declared the world free of } \\
\text { this disease. }\end{array}$ & $\begin{array}{llr}\begin{array}{l}\text { Species of } \\
\text { Orthopoxvirus }\end{array} & \text { the } & \begin{array}{r}\text { genus } \\
\text { family }\end{array} \\
\text { Poxviridae. } & & \\
& & \\
\text { Enveloped with } & \text { a } & \text { single } \\
\text { linear double } & & \text { stranded } \\
\text { DNA genome. } & & \end{array}$ & $5-7$ & $\begin{array}{l}\text { Human } \\
\text { Only. }\end{array}$ & $\begin{array}{l}\text { Fever and a } \\
\text { distinctive, } \\
\text { progressive } \\
\text { skin rash. }\end{array}$ & $\begin{array}{l}\text { Inhalation } \\
\text { of airborne } \\
\text { Variola virus. }\end{array}$ & $\begin{array}{l}\text { Smallpox } \\
\text { vaccines }\end{array}$ & $30 \%$ & $\begin{array}{l}\text { (Babkin and } \\
\text { Babkina 2015; } \\
\text { Dubochet et al. } \\
\text { 1994) }\end{array}$ \\
\hline Measles morbillivirus & $\begin{array}{l}\text { - In the early of the } 4 \text { th century BCE } \\
\text { was the first outbreak many other } \\
\text { outbreaks. } \\
\text { - Last outbreak wes in Sweden } 2017 \text { - } \\
2018 \text {. }\end{array}$ & 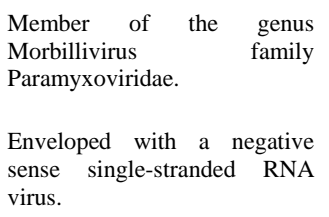 & $12-18$ & Human only. & $\begin{array}{l}\text { Rash, fever } \\
\text { and respiratory } \\
\text { symptoms. }\end{array}$ & $\begin{array}{l}\text { Passed through } \\
\text { direct contact and } \\
\text { through the air. }\end{array}$ & $\begin{array}{l}\text { Measles vaccine } \\
\text { (Live attenuated } \\
\text { vaccine). }\end{array}$ & $\begin{array}{l}20 \% \text { from } \\
\text { West Africa. } \\
\text { And } 2 \% \text { in } \\
\text { the } \\
\text { developing } \\
\text { world. }\end{array}$ & $\begin{array}{l}\text { (Chun et al. 2020; } \\
\text { Guerra et al. 2017; } \\
\text { Sundell et al. 2017) }\end{array}$ \\
\hline Yellow fever virus & $\begin{array}{l}\text { - The first definitive outbreak of } \\
\text { yellow fever in the New World was in } \\
1647 \text { on the island of Barbados. } \\
\text { Followed by many outbreaks and } \\
\text { epidemics. From the end of } 2017 \text { to } \\
\text { mid-May 2018, we experienced a YF } \\
\text { epidemic in the southern region of } \\
\text { Brazil. }\end{array}$ & $\begin{array}{l}\text { Species of the genus } \\
\text { Flavivirus, family Flaviviridae. } \\
\text { Enveloped, positive-sense, } \\
\text { single-stranded RNA viruses. }\end{array}$ & $2.6-3.4$ & $\begin{array}{l}\text { Humans, } \\
\text { other pri } \\
\text { mates, and } \\
\text { several types } \\
\text { of mosquitoes. }\end{array}$ & $\begin{array}{l}\text { Fever, } \\
\text { headache, } \\
\text { jaundice, } \\
\text { muscle pain, } \\
\text { nausea, } \\
\text { vomiting and } \\
\text { fatigue. }\end{array}$ & $\begin{array}{l}\text { Transmitted by } \\
\text { mosquitoes, } \\
\text { belonging to the } \\
\text { Aedes } \\
\text { and Haemogogus s } \\
\text { pecies. }\end{array}$ & $\begin{array}{l}\text { The yellow } \\
\text { fever vaccine. } \\
\text { (attenuated live } \\
\text { vaccine) }\end{array}$ & $20-50 \%$ & $\begin{array}{l}\text { (Gubler 2018; } \\
\text { Nasidi et al. 1989; } \\
\text { Nunes Duarte-Neto } \\
\text { et al. 2019; Zhao et } \\
\text { al. 2018) }\end{array}$ \\
\hline Zika virus & $\begin{array}{l}\text { - Uganda in } 1947 \text { last outbreak in } \\
\text { Brazil in } 2016\end{array}$ & $\begin{array}{l}\text { Member of the genus } \\
\text { Flavivirus family Flaviviridae } \\
\text { Enveloped, positive single } \\
\text { stranded genomic RNA }\end{array}$ & & $\begin{array}{l}\text { Humans and } \\
\text { mosquitoes. }\end{array}$ & $\begin{array}{l}\text { Rash, fever, } \\
\text { arthralgia, } \\
\text { conjunctivitis, } \\
\text { headache, } \\
\text { vomiting and } \\
\text { edema with } \\
\text { severe } \\
\text { neurological } \\
\text { complications } \\
\text { including } \\
\text { microcephaly } \\
\text { in newborn. }\end{array}$ & $\begin{array}{l}\text { bite of an infected } \\
\text { mosquito from the } \\
\text { Aedes Genus, } \\
\text { contaminated blood } \\
\text { and sexual } \\
\text { transmission. }\end{array}$ & $\begin{array}{l}\text { No available } \\
\text { treatment and } \\
\text { vaccine }\end{array}$ & $\begin{array}{l}8.3 \% \text { in cases } \\
\text { of } \\
\text { microcephaly }\end{array}$ & $\begin{array}{l}\text { (Heang et al. 2012; } \\
\text { Da Cunha et al. } \\
\text { 2016) }\end{array}$ \\
\hline Ebola virus disease & $\begin{array}{l}\text { its discovery in } 1976 \text { in areas of sub- } \\
\text { Saharan Africa the biggest outbreak is } \\
\text { in 2014-2016 in West Africa }\end{array}$ & $\begin{array}{l}\text { Belonged to genus Ebolavirus } \\
\text { family Filoviridae. } \\
\text { Enveloped viruses with non- } \\
\text { segmented negative- } \\
\text { sense RNA genomes. }\end{array}$ & $1.5-2.5$ & $\begin{array}{l}\text { Wild animals } \\
\text { and human }\end{array}$ & $\begin{array}{l}\text { viral } \\
\text { hemorrhagic } \\
\text { fever. }\end{array}$ & $\begin{array}{l}\text { from wild animals } \\
\text { then human-to- } \\
\text { human } \\
\text { transmission. }\end{array}$ & $\begin{array}{l}\text { Ervebo is a } \\
\text { genetically } \\
\text { engineered live } \\
\text { attenuated } \\
\text { vaccine contains } \\
\text { a protein from } \\
\text { the Zaire } \\
\text { ebolavirus. }\end{array}$ & $25-90 \%$ & $\begin{array}{l}\text { (WHO 2020; Baize } \\
\text { et al. 2014; } \\
\text { Groseth, Feldmann, } \\
\text { and Strong 2007) }\end{array}$ \\
\hline
\end{tabular}


Table 2 (contd.)

\begin{tabular}{|c|c|c|c|c|c|c|c|c|c|}
\hline Virus & Pandemics and Epidemics & Structure & $\mathbf{R 0} *$ & Host & Symptoms & Transmission & $\begin{array}{l}\text { Treatment } \\
\text { and vaccine }\end{array}$ & $\begin{array}{l}\text { Mortality } \\
\text { rate }\end{array}$ & References \\
\hline Influenza viruses & & $\begin{array}{lr}\text { family } & \text { Orthomyxoviridae } \\
\text { enveloped, } & \text { negative-stranded } \\
\text { RNA viruses } & \end{array}$ & & $\begin{array}{l}\text { Human, birds } \\
\text { and pigs }\end{array}$ & $\begin{array}{l}\text { abrupt onset of } \\
\text { headache, } \\
\text { high-grade } \\
\text { fever, chills, } \\
\text { dry cough, } \\
\text { pharyngeal } \\
\text { irritation, } \\
\text { myalgias, } \\
\text { malaise, and } \\
\text { anorexia. }\end{array}$ & $\begin{array}{l}\text { Airborne } \\
\text { transmission } \\
\text { (aerosol droplets } \\
\text { and contaminated } \\
\text { hands) }\end{array}$ & $\begin{array}{l}\text { Influenza } \\
\text { vaccines are } \\
\text { inactivated, } \\
\text { attenuated, or } \\
\text { recombinant. }\end{array}$ & & $\begin{array}{l}\text { (Taubenberger et al. } \\
\text { 2000; Taubenberger } \\
\text { and Morens 2006) }\end{array}$ \\
\hline Spanish flu (H1N1) & 1918-1919 & & $1.47-2.27$ & & & & & $4-20 \%$ & \\
\hline Asian flu (H2N2) & 1957- 1958 originated in China & & 1.6 & & & & & $<1 \%$ & \\
\hline Swine flu(H1N1) & 2009-2010 originated in Mexico & & 1.5 & & & & & $0.3 \%$ & \\
\hline Human CoronaViruses: SARS & $\begin{array}{l}\text { 2002-2003 originated in Guangdong - } \\
\text { China }\end{array}$ & $\begin{array}{l}\text { Family Coronaviridae, order } \\
\text { Nidovirales, } \\
\text { Enveloped, large, single, plus- } \\
\text { stranded RNA viruses }\end{array}$ & $2-5$ & $\begin{array}{l}\text { Bats, civets } \\
\text { and human }\end{array}$ & $\begin{array}{l}\text { Fever, cough, } \\
\text { chest pain and } \\
\text { maybe } \\
\text { pneumonia }\end{array}$ & $\begin{array}{l}\text { Respiratory droplet } \\
\text { transmission. }\end{array}$ & $\begin{array}{l}\text { No available } \\
\text { treatment and } \\
\text { vaccine. }\end{array}$ & $10 \%$ & $\begin{array}{l}\text { (Desforges et al. } \\
\text { 2019; Bauch and } \\
\text { Oraby 2013; } \\
\text { Ashour et al. 2020; } \\
\text { Wilson et al. 2020; }\end{array}$ \\
\hline MERS & $\begin{array}{l}\text { 2015- till now. Originated in Saudi } \\
\text { Arabia. }\end{array}$ & & $\begin{array}{l}<1(0 \cdot 6- \\
9)\end{array}$ & $\begin{array}{l}\text { Bats, camels } \\
\text { and human. }\end{array}$ & & & & $40 \%$ & Oboho et al. 2015) \\
\hline COVID-19 & $\begin{array}{l}\text { 2019- till now. Originated in Wuhan, } \\
\text { China }\end{array}$ & & $1.4-5.5$ & $\begin{array}{l}\text { Human and } \\
\text { Unknown } \\
\text { origin. }\end{array}$ & $\begin{array}{l}\text { fever, cough, } \\
\text { and myalgia or } \\
\text { fatigue. }\end{array}$ & & & $3.4 \%$ & \\
\hline
\end{tabular}

Table 2 Different types of serology tests

\begin{tabular}{|c|c|c|c|c|}
\hline Test type & Time to results & Sample & Data obtained & Missed data \\
\hline Rapid diagnostic test (RDT) & 10-30 minutes & $\begin{array}{l}\text { Blood, serum, saliva } \\
\text { samples, or nasal swab } \\
\text { fluids }\end{array}$ & $\begin{array}{l}\text { Qualitative detection of antibodies against the } \\
\text { virus in patient sample. }\end{array}$ & $\begin{array}{l}\text { Quantification detection of antibodies and the } \\
\text { ability of antibodies to protect against future } \\
\text { viral infection. }\end{array}$ \\
\hline $\begin{array}{l}\text { Enzyme linked immunosorbent } \\
\text { assay (ELISA) }\end{array}$ & $1-5$ hours & $\begin{array}{l}\text { whole blood, plasma, } \\
\text { or serum samples }\end{array}$ & $\begin{array}{l}\text { Quantitative and/or qualitative detection of } \\
\text { antibodies against the virus in patient serum or } \\
\text { blood. }\end{array}$ & $\begin{array}{l}\text { The ability of antibodies to protect against } \\
\text { future viral infection. }\end{array}$ \\
\hline Neutralization assay & 3-5 days & $\begin{array}{l}\text { whole blood, serum, or } \\
\text { plasma samples }\end{array}$ & $\begin{array}{l}\text { Detect the active antibodies (that can protect } \\
\text { against future infection) in patient serum and } \\
\text { can inhibit virus replication ex vivo, in a cell } \\
\text { culture system. }\end{array}$ & $\begin{array}{l}\text { The antibodies to viral proteins that are not } \\
\text { involved in replication. }\end{array}$ \\
\hline
\end{tabular}


Wrapp et al. (2020) found that the cryo-electron microscopy of SARS-CoV-2 S protein illustrate that the $\mathrm{S} 1 / \mathrm{S} 2$ subunits, which is furin subunit, are the first cleavage site and is the main difference between SARSCoV-2 from SARS-CoV and SARS-related CoVs. Coronaviruses $\mathrm{S}$ protein is additionally cleaved by cellular proteases of the host at S2' site, within S2 subunit, like human airway trypsin-like protease (HAT), cathepsins and transmembrane protease serine 2 (TMPRSS2) then they proposed to activate the fusion protein by many irreversible conformational changes (Millet and Whittaker 2015; Park et al. 2016). Spike (S), envelope (E), membrane (M) and nucleocapsid $(\mathrm{N})$ genes are four structural genes that encode the structural proteins.

The non-structural proteins that are vital for viral replication are generated by the proteolytic cleavage of the polyprotein at 11 different sites (Anand et al. 2003). These processes are mediated by non-structural proteins 3-chymotrypsin-like protease $\left(3 \mathrm{CL}^{\mathrm{pro}}\right)$ or also called main protease $\left(\mathrm{M}^{\mathrm{pro}}\right)$ which plays a very important role in the virus replication and a potential target for drug development (Needle et al. 2015).

The SARS-CoV-2 $3 \mathrm{CL}^{\mathrm{pro}}$ polypeptide is considered as a stable protein, a hydrophilic molecule capable of establishing hydrogen bonds, and an important target for anti-SARS-CoV-2 inhibitors. The molecular weight of $3 \mathrm{CL}^{\text {pro }}$ polypeptide is $33,796.64 \mathrm{Da}$ with 306 amino acids and a GRAVY score of -0.019 (ul Qamar et al. 2020).

\section{Pathogenesis of COVID-19}

Pathogenesis of Covid-19 from the point of entry of the lungs till the appearance of the symptoms is poorly investigated. To fully understand the pathogenesis of COVID-19, we must understand the mechanisms of MERS-CoV and SARS-CoV as the genetic system of the COVID-19 displayed more than $80 \%$ and $50 \%$ similarity for SARS-CoV and MERS-CoV, respectively (Lu et al. 2020; Ren et al. 2020). Pathogenesis of COVID-19 is divided into 3 parts including viral entry and replication, cytokine storm and corona virus immune evasion.

\section{Viral entry and replication}

The envelope S glycoprotein causing attachment of viral particles to the host cells ( $\mathrm{Li}$ et al. 2003). After the entry of the virus to the cells, the viral RNA genome is released into the cytoplasm and converted into structural proteins and polyproteins, after which the viral genome starts to replicate (Perlman and Netland 2009). Then, viral particles germinate into the endoplasmic reticulum-Golgi intermediate compartment (ERGIC). Finally, the vesicles containing the virus particles fuse with the plasma membrane to release the virus to outside the infected cells (De Wit et al. 2016).

\section{Cytokine storm in COVID-19}

Acute Respiratory Distress Syndrome (ARDS) is the common immunopathological episode for SARS-CoV, COVID-19 and MERS-CoV infections (Xu et al. 2020). In case of SARS-CoV infection, the main mechanism for ARDS is the cytokine storm which is the uncontrolled deadly systemic inflammatory response resultant from the release of large amounts of pro-inflammatory cytokines (IL-1 $\beta$, IL-6I, IL-18, IL-33, IL-12, FN- $\alpha$, IFN- $\gamma$, TNF- $\alpha$, TGF $\beta$, etc.) and chemokines (CXCL8, CXCL9, CXCL10, CCL2, CCL3, CCL5, etc.) by immune effector cells (Channappanavar and Perlman 2017). The cytokine storm triggers a vicious attack by the immune system to the body, causing ARDS and multiple organ failure which may finally lead to death in severe cases of COVID-19, just like what occurs in SARS-CoV (Xu et al. 2020).

\section{Coronavirus immune evasion}

To improve survival in host cells, MERS-CoV and SARS-CoV use numerous strategies to avoid the immune counterattack. The conserved microbial structures named pathogen-associated molecular patterns (PAMPs) can be recognized by pattern recognition receptors (PRRs) which play a crucial rule in the function of the innate immune system. However, SARS-CoV and MERS-CoV can produce double-membrane vesicles that don't contain PAMPs and begin replication in these vesicles, by this means it avoids the host detection of their dsRNA (de Wilde et al. 2017).

\section{Symptoms and Risk factors of COVID-19}

The most common symptoms in patients with COVID-19 were fever, cough, and dyspnea. By contrast, upper respiratory tract symptoms were less common in these patients, indicating that the cells targeted by the virus might be in the lower airway. Other non-specific symptoms included dizziness, diarrhea, vomiting, headache, and generalized weakness, which occurred in around $2-9 \%$ of patients. Notably, abnormal lung findings on CT scans can help in the diagnosis of asymptomatic infected patients, (Shi et al. 2020) suggested that chest CT scans or serum antibody tests should be done in asymptomatic high-risk individuals with a history of exposure to patients with COVID-19 to facilitate early identification of the disease.

The results of the study have been done by (Chen et al.2020) on 9 pregnant women with confirmed COVID19 infection showed that the clinical features were similar with that reported in non-pregnant women, none of them 
developed severe pneumonia or died of COVID-19 pneumonia and no evidence of vertical transmission of COVID-19 infection (Karimi-Zarchi et al. 2020).

Children are not far away from COVID-19; it spreads rapidly in children, so it suggests that it has a strong transmission capacity in the special population (neonate, children). The potential risk of transmission maybe because of the delayed clearance of viral RNA unaffected by the severity of symptoms. An observational cohort study in China was conducted on 36 confirmed COVID19 children and found that $28 \%$ were asymptomatic, $19 \%$ with upper respiratory symptoms and 53\% had moderate symptoms and mild pneumonia. The clinical features of COVID- 19 infection were found to be milder in children than adults (Qiu et al. 2020).

Blood levels of d-dimer and Sequential Organ Failure Assessment (SOFA) scores were higher in critically ill or fatal cases, whereas lymphopenia and cardiovascular disease have been less commonly observed in non-critical or surviving patients with COVID-19 infection. Other risk factors, including older age and high fever were associated with a greater risk of development of ARDS and death (Wu et al. 2020). Zhou et al. (2020) found that around half of confirmed patients had comorbidity, 30\% of them with hypertension, $19 \%$ diabetics and the rest with coronary heart disease.

\section{Transmission and incubation period of COVID-19}

COVID-19 spreads via direct contact routs, droplets or by touching any surface carrying the droplet then touch your face, eyes, nose, mouth or ear (Singhal 2020). In general, coronavirus can persist on inanimate objects and surfaces like metal, glass or plastic for up to 9 days, at room temperature according on the material of the surface and its concentration can reach about 100 million viral particles per $\mathrm{ml}$ in sputum (Cleri et al. 2010).

Ong et al. (2020) reported that COVID-19 is not an airborne transmission disease in an investigation for 75,465 Chinese patients suffering from COVID-19 infection. In hospitals, SARS-CoV-2 might be aerosol transmitted up to 4 meters (13 feet) in both ICU and general wards which considered a high infection risk for medical staff and other close contacts (Guo et al. 2020).

The environment can affect the human-to-human transmission of SARS-CoV-2, where unsuitable climates other than average temperatures of $5-11^{\circ} \mathrm{C}$, and absolute humidity (4-7 g/m3) can reduce the stability of the virus and reduce its transmission (Sajadi et al. 2020). It is still unclear if SARS-CoV-2 will be able to spread in all seasons as MERS or unable to sustain itself with high temperature and disappear, just as SARS-CoV did so in 2003.
WHO (2020) has stated that the incubation period of COVID-19 between 2 days to 2 weeks. Although several studies confirm a 14-day medical incubation period for patients exposed to the virus, there is some literature supposes that the incubation period of this virus can be extended more than two weeks and it is reflected double exposure of infection (Wu et al. 2020). The time from the start of symptoms of COVID-19 to death estimated to ranges from 1 week to 6 weeks with an average time estimated to be 2 weeks ( $\mathrm{Wu}$ et al. 2020). This time is dependent on various factors includes the status of the patient's immune system and age.

\section{Diagnosis of COVID-19}

COVID-19 diagnosis is mostly depending on clinical manifestations, epidemiological history, and some secondary examinations, such as CT scan, nucleic acid detection, immune identification technology Point-of-care Testing (POCT) of IgM/IgG, blood culture and enzymelinked immunosorbent assay (ELISA). However, the clinical symptoms and signs of the infected patients with COVID-19 alone are highly atypical and cannot be used alone, so, secondary examinations and epidemiological history are essential for the diagnosis of COVID-19 (Cederroth and Nef 2009). Here we will discuss the three most important detection methods as following:

\section{Nucleic acid detection technology}

The two commonly used nucleic acid detection technologies for COVID-19 are high-throughput sequencing and real-time quantitative polymerase chain reaction (RT-qPCR). The sequencing method is of limited use in clinical diagnosis, due to its high cost and equipment dependency (Zhou et al. 2020). Therefore, RTqPCR is the most effective, common and straightforward way for identifying pathogenic viruses in blood and respiratory secretions. The Chinese Center for Disease Control and Prevention (China CDC) recommends the use of specific primers and probes in the $\mathrm{N}$ gene and ORF1ab regions for the detection of COVID-19 by RTqPCR and is confirmed positive patient when both targets are positive.

\section{CT scans and other diagnostic methods}

Although RT-qPCR for the diagnosis of COVID-19 is specific, its false-negative percentage cannot be mistreated due to the serious consequences of missed diagnosis. CT scan, proposed by many clinicians, should be a necessary secondary diagnostic method (Xie et al. 2020). For persons with a high clinical suspicion of COVID-19 infection with negative RT-qPCR screening, a 
combination of repeated RT-qPCR tests and the beginning of a chest CT scan may be useful. CT images typically show bilateral pulmonary parenchymal groundglass and consolidative pulmonary opacities, sometimes with a peripheral lung distribution and a rounded morphology, these findings also were observed in patients with MERS-CoV and SARS-CoV (Ajlan et al. 2014; Ooi et al. 2004 ).

\section{Serology assays}

The demand to discover serology testing for SARS-CoV2 is increased for better detection and surveillance of cases of COVID-19, including those that may be asymptomatic or have recovered. On the $1^{\text {st }}$ of April 2020, The Food and Drug Administration (FDA) has authorized one Emergency Use Authorization (EUA) for a serological test to be used in clinical laboratories (Table 2). To date, over 70 serological tests are available and ready to be used (Stephen 2020). Immunoassays are less accurate than PCR, but they are easier to use and rapid as it delivers results in 20-60 minutes (Sheridan 2020).

\section{Treatment and vaccination}

In general, there are no confirmed specific antiviral drugs or effective vaccines for SARS-CoV-2 or any other human $\mathrm{CoV}$ infection to date. All the drug options come from experience treating SARS, MERS, or some other new influenza virus.

Active symptomatic support remains key to treatment (Cascella et al. 2020). Among all the studies conducted and the clinical trials for numerous candidate drugs, this study will show the drugs with a positive and promising impact so far. Chloroquine a known drug for the treatment of malaria and autoimmune disease (Guo et al. 2020). It was also found to possess antiviral activity against RNA viruses like HIV (Boelaert et al. 2001), hepatitis C virus (Mizui et al. 2010) and influenza A H5N1 virus (Yan et al. 2013). Chloroquine also found to be used for the prevention and therapeutic of SARS-CoV and SARS-CoV-2 infections by elevation of endosomal $\mathrm{pH}$ required for virus/cell fusion, as well as interfering with the glycosylation of host receptors (ACE-2) of SARS-CoV (Vincent et al. 2005; Wang et al. 2020).

The Hydroxychloroquine was preferred than chloroquine for the treatment of SARS-CoV-2 infection for these reasons; (i) hydroxychloroquine is likely to attenuate the severe progression of COVID-19 through inhibiting the cytokine storm by reducing CD154 expression in T cells; (ii) hydroxychloroquine may confer a similar antiviral effect at both pre- and post-infection stages, as found with chloroquine; (iii) 14 hydroxychloroquine has fewer side effects, safe in pregnancy and cheaper (Zhou et al.2020).

Elfiky (2020) found that sofosbuvir, ribavirin, and remdesivir showed promising results against the SARSCoV-2 after in-silico testing. The FDA approved antiparasitic drug ivermectin, showed broad-spectrum invitro anti-viral activity and ability to reduce SARS-CoV-2 titer by 5000 -fold at 48 hours (Caly et al. 2020).

Lim et al. (2020) found that Kaletra (lopinavir/ ritonavir) showed improved clinical symptoms during the treatment with a reduction in the viral load, and they recommended their use with relatively high-risk groups of COVID-19 pneumonia. On the other hand, Cao et al. (2020) observed that in hospitalized patients with severe COVID-19, there were no benefits on viral load or mortality rate with lopinavir/ ritonavir compared to standard treatment. For children with confirmed COVID19, lopinavir-ritonavir is of choice for treatment in combination with a low dosage of nebulized IFN- $\alpha$, or ribavirin (Wang and Zhu 2020).

Favipiravir is another antiviral drug that has been approved in Japan in 2014 for the treatment of pandemic influenza virus and other RNA viral infections (Delang et al. 2018). A preprint randomized clinical trial found that in moderate COVID-19 patients, favipiravir can be considered as a safer and preferred treatment compared to arbidol (antivirus used in the treatment of influenza) because of superior clinical recovery rate and more effectively reduced incidence of fever, cough (Chen et al. 2020).

As recently being investigated, therapeutic plasma exchange (TPE) has made a huge impact as an alternative treatment for seriously ill COVID-19 patients.

Convalescent plasma also called passive antibody therapy, is a type of passive immunity that can provide antibodies from the host which is COVID-19 patient to another host, but the proteins will only last for a short period of time like weeks or maybe a few months. Keith et al. (2020) have been mentioned in their trial the mortality rate of 80 seriously ill patients on the ventilator had decreased from being $81 \%$ to $47.3 \%$ which proves the impact of TPE. Recently the FDA has approved the TPE to be regulated as an investigational product that can be tested clinically or due to the vicious pandemic which can be tested against patients with serious or immediately life-threatening Covid-19 (FDA, 2020). The Ministry of Health in Egypt also apply TPE therapy from recovered patients and described oseltamivir, hydroxychloroquine, chloroquine or lopinavir/ritonavir for mild and severe ICU care.

Vaccination development activities of COVID-19 are distributed over 19 countries including $46 \%$ of developers in North America, China, others in Asia and Europe. 
However, there is no information about any developers in Africa and Latin America. As shown in figure (5), these pipelines categorized into exploratory early planning without in-vivo testing (confirmed and unconfirmed), and preclinical in the in-vivo stage and/or phase I manufacturing clinical trials (Le et al. 2020).

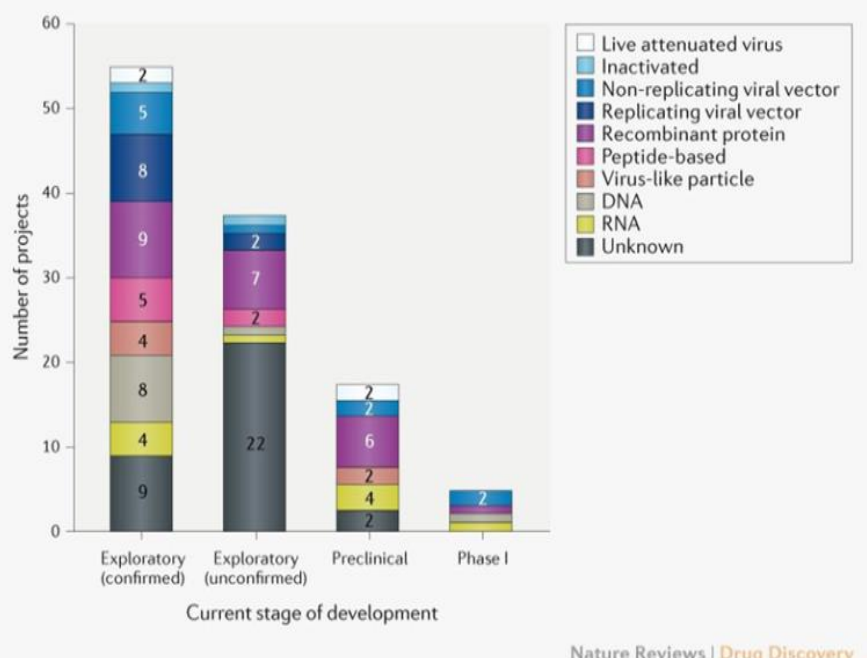

Fig 5. COVID-19 vaccination candidates in pipelines by technology platform. (Le et al., 2020).

\section{Prevention and control}

Social distancing is one of the most important decisions taken by policy makers as school closure which alone would prevent only 2-4\% of COVID-19 deaths (Viner et al. 2020). Other prevention parameters include washing hands, wearing masks and sanitizing surfaces contribute to decreasing the outbreak of virus. Coronaviruses can be significantly inhibited and inactivated by disinfecting the surfaces using $62-71 \%$ ethanol, $0.1 \%$ sodium hypochlorite or $0.5 \%$ hydrogen peroxide for $1 \mathrm{~min}$. Personal quarantine, travel restrictions, besides staying home if person is sick, except to get medical care is success trials for controlling outbreak of COVID-19. Boosting the immunity is very important in fighting the pathogens through different nutrients such as; edible mushrooms, wheat germ, yogurt, tea, sweet potato, broccoli and garlic. All these food contain different supplementary materials such as; selenium, vitamins, antioxidants, probiotics, omega-3, zinc and iron (Zhang and Liu, 2020).

\section{Conclusion and future prospective}

The COVID-19 disease induces clusters of lethal pneumonia with serious clinical features similar to SARS$\mathrm{CoV}$. In the lack of vaccines and deficiency of antivirals, it is necessary to monitor the spread of COVID-19 using many aspects. First, empathize the susceptibility of these viruses to transmit between different species, to recognize the viral infection in new hosts as well as the detection of coronaviruses reservoirs will effectively help to predict where and when potential infection may happen. Second, several of the non-structural proteins encoded by coronaviruses genomes still uncharacterized till now with unknown functions and unidentified biological roles, and it will be interest to explore the molecular mechanisms of these proteins as well as identifying their role in pathogenesis and viral replication. Third, in addition to discovering new antivirals and clinical investigation of old drugs, developing and design, new vaccines for COVID-19 is also required. Fourth, getting a comprehensive knowledge of particulars of some viral replication enzymes such as replicase transcriptase will aid on empathizing the unique process of RNA replication used by coronaviruses, leading to develop a new inhibitors or competitors for these enzymes. Fifth, developing new vaccines target $\mathrm{S}$ protein or the spike protein owing to its role in the stimulation of protective immunity through infection with COVID-19 by inducing T-cell responses and neutralizing-antibodies. As a summary in order to know more and discover the hidden secrets beyond the COVID-19 we should study carefully different parameters and they are summarized in graphical abstract. Finally, exploring the mechanism of how COVID-19 caused and improving the immunity of patients and contacted persons will be potentially improve their health and reduce the morbidity and mortality rates.

\section{Conflict of interest}

The authors have no conflicts of interest to declare. All co-authors have seen and agree with the contents of the manuscript. 


\section{References}

Ajlan AM, Ahyad RA, Jamjoom LG, Alharthy A and Madani TA (2014) Middle East respiratory syndrome coronavirus (MERS-CoV) infection: Chest CT findings. Am. J. Roentgenol. 203:782-787

Anand K, Ziebuhr J, Wadhwani P, Mesters JR and

kejima K, Kitamura $\mathrm{T}$, Enomoto $\mathrm{N}$, Sakai $\mathrm{T}$ and Kominami E (2010) Inhibition of hepatitis C virus replication by chloroquine targeting virus-associated autoph.

Hilgenfeld R (2003) Coronavirus main proteinase (3CLpro) Structure: Basis for Design of Anti-SARS Drugs. Science 300(80):1763-1767.

https://doi.org/10.1126/science.1085658

Araujo MB and Naimi B (2020) Spread of SARS-CoV-2 Coronavirus likely to be constrained by climate. medRxiv.

https://doi.org/10.1101/2020.03.12.20034728

Ashour HM, Elkhatib WF, Rahman MM, Elshabrawy HA (2020) Insights into the recent 2019 novel Coronavirus (SARS-CoV-2) in light of past human Coronavirus Outbreaks. Pathog (Basel, Switzerland) 9:1-15. https://doi.org/10.3390/pathogens9030186

Babkin I V, Babkina IN (2015) The Origin of the Variola Virus. Viruses 7:1100-1112. https://doi.org/10.3390/v7031100

Baize S, Pannetier D, Oestereich L, Rieger T, Koivogui L, Magassouba NF, Soropogui B, Sow MS, Keïta S De Clerck H, and Tiffany A (2014) brief report emergence of Zaire Ebola Virus disease in Guinea. N Engl J Med

371:1418-1443. https://doi.org/10.1056/NEJMoa1404505

Bauch CT, Oraby T (2013) Comment assessing the pandemic potential of MERS-CoV. https://doi.org/10.1016/S0140-6736(13)61504-4

Berry M, Gamieldien J, Fielding BC (2015) Identification of new respiratory viruses in the new millennium. Viruses 7:996-1019. https://doi.org/10.3390/v7030996

Bertram S, Glowacka I, Müller MA, Lavender H, Gnirss K, Nehlmeier I, Niemeyer D, He Y, Simmons G, Drosten C and Soilleux EJ (2011) Cleavage and activation of the severe acute respiratory syndrome coronavirus spike protein by human airway trypsin-like protease. J Virol 85:13363-72

Biscayart C, Angeleri P, Lloveras S, Chaves TDSS, Schlagenhauf P, and Rodríguez-Morales AJ (2020) The next big threat to global health? 2019 novel coronavirus (2019-nCoV): What advice can we give to travellers? - Interim recommendations January 2020, from the Latin-American society for Travel Medicine (SLAMVI). Travel Med Infect Dis 33:17-20. https://doi.org/10.1016/j.tmaid.2020.101567

Boelaert JR, Piette J, Sperber K (2001) The potential place of chloroquine in the treatment of HIV-1-infected
Microbial Biosystems 5(1)-2020

patients. J Clin Virol 20:137-140.

https://doi.org/10.1016/S1386-6532(00)00140-2

Brasil P, Pereira JP, Moreira ME, Ribeiro Nogueira RM, Damasceno L, Wakimoto M, Rabello RS, Valderramos SG, Halai UA, Salles TS and Zin AA (2016) Zika virus infection in pregnant women in rio de janeiro. $\mathrm{N}$ Engl $\mathbf{J}$ Med 375:2321-2334.

https://doi.org/10.1056/NEJMoa1602412

Caly L, Druce JD, Catton MG, Jans DA and Wagstaff KM (2020) The FDA-approved Drug Ivermectin inhibits the replication of SARS-CoV-2 in vitro. Antiviral Res 104787. https://doi.org/10.1016/j.antiviral.2020.104787

Cao B, Wang Y, Wen D, Liu W, Wang J, Fan G, Ruan L, Song B, Cai Y, Wei M and Li X (2020) A trial of lopinavir-ritonavir in adults hospitalized with severe covid-19. N Engl J Med 382:1787-1799.

https://doi.org/10.1056/NEJMoa2001282

Cascella M, Rajnik M, Cuomo A, Dulebohn SC and Di Napoli R (2020) Features, evaluation and treatment Coronavirus (COVID-19). StatPearls Publishing

Cederroth CR, Nef S (2009) Molecular and Cellular Endocrinology Soy, phytoestrogens and metabolism: A review. 304:30-42.

https://doi.org/10.1016/j.mce.2009.02.027

Channappanavar R, Perlman S (2017) Pathogenic human coronavirus infections: causes and consequences of cytokine storm and immunopathology. Semin. Immunopathol. 39:529-539

Chen C, Huang J, Cheng Z, Wu J, Chen S, Zhang Y, Chen B, Lu M, Luo Y, Zhang J and Yin P (2020) Favipiravir versus Arbidol for COVID-19: A randomized clinical trial. medRxiv 2020.03.17.20037432. https://doi.org/10.1101/2020.03.17.20037432

Chen H, Guo J, Wang C, Luo F, Yu X, Zhang W, Li J, Zhao D, Xu D, Gong Q and Liao J (2020) Clinical characteristics and intrauterine vertical transmission potential of COVID-19 infection in nine pregnant women: a retrospective review of medical records. Lancet 395:809-815. https://doi.org/10.1016/S01406736(20)30360-3

Chun JY, Park WB, Kim NJ, Choi EH, Funk S and Oh MD (2020) Estimating contact-adjusted immunity levels against measles in South Korea and prospects for maintaining elimination status. Vaccine 38:107111. https://doi.org/10.1016/j.vaccine.2019.10.040

Cleri DJ, Ricketti AJand Vemaleo JR (2010) Severe acute respiratory syndrome (SARS). Infect Dis Clin N Am 24:175-200

Cleri DJ, Ricketti AJ, Vernaleo JR (2010) Severe acute respiratory syndrome (SARS). Infect Dis Clin North Am 24:175-202. https://doi.org/10.1016/j.idc.2009.10.005

Coleman RE (2006) Clinical features of metastatic bone 
El-Maradny et al. 2020

disease and risk of skeletal morbidity. Clin Cancer Res $12: 6243 \mathrm{~s}-6249 \mathrm{~s}$.

https://doi.org/10.1158/1078-0432.CCR-06-0931

Da Cunha AJLA, De Magalhães-Barbosa MC, Lima-Setta F, de Andrade Medronho R and Prata-Barbosa A (2016) Microcephaly case fatality rate associated with Zika virus infection in Brazil. Pediatr Infect Dis $\mathbf{J}$ 36:528-530.

https://doi.org/10.1097/INF.0000000000001486

De Groot RJ, Baker SC, Baric RS, Brown CS, Drosten C, Enjuanes L, Fouchier RA, Galiano M, Gorbalenya AE, Memish ZA and Perlman S (2013) Middle East respiratory syndrome Coronavirus (MERS-CoV): Announcement of the Coronavirus study group. J Virol 87:7790-7792.

https://doi.org/10.1128/jvi.01244-13

De Serres G, Markowski F, Toth E, Landry M, Auger D, Mercier M, Bélanger $\mathrm{P}$, Turmel B, Arruda H, Boulianne N and Ward BJ (2013) Largest Measles Epidemic in North America in a Decade-Quebec, Canada, 2011: contribution of susceptibility, serendipity, and superspreading Events. https://doi.org/10.1093/infdis/jis923

De Wilde AH, Snijder E.J, Kikkert M and van Hemert MJ (2017) Host Factors in Coronavirus replication. In: Tripp R.; Tompkins S. (eds) Roles of host gene and non-coding RNA expression in virus infection. In: Current Topics in Microbiology and Immunology; vol 419. Springer; Cham. pp 1-42

De Wit E, Van Doremalen N, Falzarano D, Munster VJ (2016) SARS and MERS: Recent insights into emerging coronaviruses. Nat. Rev. Microbiol. 14:523534

Delang L, Abdelnabi R. and Neyts J (2018) Favipiravir as a potential countermeasure against neglected and emerging RNA viruses. Antiviral Res 153:85-94. https://doi.org/10.1016/j.antiviral.2018.03.003

Desforges M, Le Coupanec A, Dubeau P, Bourgouin A, Lajoie L, Dubé M and Talbot PJ (2019) Human coronaviruses and other respiratory viruses: Underestimated opportunistic pathogens of the central nervous system? Viruses 12:1-28.

https://doi.org/10.3390/v12010014

Drosten C, Günther S, Preiser W, Van Der Werf S, Brodt HR, Becker S, Rabenau H, Panning M, Kolesnikova L, Fouchier RA and Berger A (2003) Identification of a novel Coronavirus in patients with severe acute respiratory syndrome. N Engl J Med 348:1967-1976

Dubochet J, Adrian M, Richter K, Garces J and Wittek R (1994) Structure of intracellular mature vaccinia virus observed by cryoelectron microscopy. J Virol 68(3):1935-1941.

Ehrhardt SA, Zehner M, Krähling V, Cohen-Dvashi H, Kreer C, Elad N, Gruell H, Ercanoglu MS, Schommers
P, Gieselmann L and Eggeling R (2019) Polyclonal and convergent antibody response to Ebola virus vaccine rVSV-ZEBOV. Nat Med 25(10), 1589-1600. https://doi.org/10.1038/s41591-019-0602-4

Elfiky A.A (2020) Anti-HCV, nucleotide inhibitors, repurposing against COVID-19. Life sciences, p.117477. https://doi.org/10.1016/j.lfs.2020.117477

European Centre for Disease Prevention and Control (ECDC) (2020) Coronavirus Pandemic (COVID-19) the data - Our World in Data.

https://github.com/owid/covid-19

data/tree/master/public/data

FDA (2020) Recommendations for Investigational COVID-19 Convalescent Plasma.

https://www.fda.gov/vaccinesbloodbiologics/investigat ional-new-drug-ind-ordeviceexemption-ide-process cber/recommendationsinvestigational-covid-19 convalescent-plasma.

Fehr AR, Perlman S (2015) Coronaviruses: An overview of their replication and pathogenesis. Methods Mol Biol 1282: https://doi.org/10.1007/978-1-4939-24387_1

Groseth A, Feldmann H, Strong JE (2007) The ecology of Ebola virus. Trends Microbiol 15:408-16.

https://doi.org/10.1016/j.tim.2007.08.001

Gubler DJ (2018) Pandemic yellow fever: a potential threat to global health via travelers. J Travel Med 25:1-2. https://doi.org/10.1093/jtm/tay097

Guerra FM, Bolotin S, Lim G, Heffernan J, Deeks SL, L, $Y$ and Crowcroft NS (2017) The basic reproduction number (R0) of measles: a systematic review. Lancet Infect Dis 17:e420-e428. https://doi.org/10.1016/S1473-3099(17)30307-9

Guo ZD, Wang ZY, Zhang SF, Li X, Li L, Li C, Cui Y, $\mathrm{Fu}$ RB, Dong YZ, Chi XY and Zhang MY (2020) Aerosol and surface distribution of severe acute respiratory Syndrome Coronavirus 2 in Hospital Wards, Wuhan, China, 2020. Emerg Infect Dis 26.

https://doi.org/10.3201/eid2607.200885

Heald-Sargent T, Gallagher T (2012) Ready, set, fuse! the coronavirus spike protein and acquisition of fusion competence. Viruses 4:557-580.

https://doi.org/10.3390/v4040557

Heang V, Yasuda CY, Sovann L, Haddow AD, da Rosa APT, Tesh RB and Kasper MR (2012) Zika virus infection, Cambodia, 2010. Emerg Infect Dis 18:349351. https://doi.org/10.3201/eid1802.111224

Hennessey M, Fischer M, Staples JE (2016) Zika Virus Spreads to New Areas - Region of the Americas.Am J Transplant 16:1031-1034. https://doi.org/10.1111/ajt.13743

Johansson MA, Vasconcelos PFC, Staples JE (2014) The whole iceberg: estimating the incidence of yellow fever virus infection from the number of severe cases. 
https://doi.org/10.1093/trstmh/tru092

Karimi-Zarchi M, Neamatzadeh H, Dastgheib SA, Abbasi $\mathrm{H}$, Mirjalili SR, Behforouz A, Ferdosian F and Bahrami R (2020) Vertical transmission of Coronavirus disease 19 (COVID-19) from infected pregnant mothers to neonates: A Review. Fetal Pediatr Pathol $0: 1-5$. https://doi.org/10.1080/15513815.2020.1747120

Keith P, Day M, Perkins L, Moyer L, Hewitt K and Wells A (2020) A novel treatment approach to the novel coronavirus: An argument for the use of therapeutic plasma exchange for fulminant COVID-19. Crit Care 24:1-3. https://doi.org/10.1186/s13054-020-2836-4

Khalifa I, Zhu W, Nafie MS, Dutta K and Li C (2020) Anti-COVID-19 Effects of Ten Structurally Different Hydrolysable Tannins through Binding with the Catalytic-Closed Sites of COVID-19 Main Protease: An In-Silico Approach.

Doi 1020944/Preprints2020030277V1 1-21.

Ksiazek TG, Erdman D, Goldsmith CS, Zaki SR, Peret T, Emery S, Tong S, Urbani C, Comer JA, Lim W RP (2003) A novel Coronavirus associated with severe acute respiratory syndrome. N Engl J Med 348:195366.

Le TT, Andreadakis Z, Kumar A, Román RG, Tollefsen S, Saville M and Mayhew S (2020) The COVID-19 vaccine development landscape. Nat Rev Drug Discov 19(5):305-6. https://doi.org/10.1038/d41573-020-00073-5

Li W, Moore MJ, Vasilieva N, Sui J, Wong SK, Berne MA, Somasundaran M, Sullivan JL, Luzuriaga K, Greenough TC and Choe H (2003) Angiotensinconverting enzyme 2 is a functional receptor for the SARS coronavirus. Nature 426:450 - 454 .

https://doi.org/https://doi.org/10.1038/nature02145

Lim J, Jeon S, Shin HY, Kim MJ, Seong YM, Lee WJ, Choe KW, Kang YM, Lee B and Park, S.J. (2020) Case of the index patient who caused tertiary transmission of coronavirus disease 2019 in Korea: The application of lopinavir/ritonavir for the treatment of COVID-19 pneumonia monitored by quantitative RT-PCR. J Korean Med Sci 35:1-6.

https://doi.org/10.3346/jkms.2020.35.e88

Liu Y, Gayle AA, Wilder-Smith A and Rocklöv J (2020) The reproductive number of COVID-19 is higher compared to SARS coronavirus. J Travel Med 1-4. https://doi.org/10.1093/jtm/taaa021

Lu R, Zhao X, Li J, Niu P, Yang B, Wu H, Wang W, Song H, Huang B, Zhu N and Bi Y (2020) Genomic characterization and epidemiology of 2019 novel coronavirus: implications for virus origins and receptor binding. Lancet 395(10224):565-74.

https://doi.org/10.1016/S0140-6736(20)30251-8

Madu IG, Roth SL, Belouzard S and Whittaker GR (2009) 18
Characterization of a highly conserved domain within the severe acute respiratory syndrome Coronavirus spike protein S2 domain with characteristics of a viral fusion Peptide. J Virol 83:7411-7421.

https://doi.org/10.1128/jvi.00079-09

Marí Saéz A, Weiss S, Nowak K, Lapeyre V, Zimmermann F, Düx A, Kühl HS, Kaba M, Regnaut S, Merkel K and Sachse A Investigating the zoonotic origin of the West African Ebola epidemic. EMBO molecular medicine 7(1):17-23.

https://doi.org/10.15252/emmm.201404792

Meltzer MI, Damon I, LeDuc JW, Millar JD (2001) Modeling potential responses to smallpox as a bioterrorist weapon. Emerg Infect Dis 7:959-969. https://doi.org/10.3201/eid0706.010607

Millet JK, Whittaker GR (2015) Host cell proteases: Critical determinants of coronavirus tropism and pathogenesis. Virus Res 202:120-134.

https://doi.org/10.1016/j.virusres.2014.11.021

Mizui T, Yamashina S, Tanida I, Takei Y, Ueno T, Sakamoto N, Iagy. J Gastroenterol 45:195-203.

https://doi.org/10.1007/s00535-009-0132-9

Nasidi A, Monath TP, DeCock K, Tomori O, Cordellier R, Olaleye OD, Harry TO, Adeniyi JA, Sorungbe AO, Ajose-Coker AO and van Der Laan G (1989) Urban yellow fever epidemic in western Nigeria. Trans Roy Soc Trop Med Hyg 83(3), 401-406.

Needle D, Lountos GT, Waugh DS (2015) Structures of the Middle East respiratory syndrome coronavirus 3Clike protease reveals insights into substrate specificity. Acta Crystallogr Sect D Biol Crystallogr 71:11021111. https://doi.org/10.1107/S1399004715003521

Duarte-Neto AN, de Almeida Monteiro RA, Johnsson J, dos Passos Cunha M, Pour SZ, Saraiva AC, Ho YL, da Silva LF, Mauad T, de Andrade Zanotto PM and Saldiva PH (2019) Ultrasound-guided minimally invasive autopsy as a tool for rapid post-mortem diagnosis in the 2018 Sao Paulo yellow fever epidemic: Correlation with conventional autopsy. PLoS negl tropi dis 13(7):e0007625.

https://doi.org/10.1371/journal.pntd.0007625

Oboho IK, Tomczyk SM, Al-Asmari AM, Banjar AA, Al-Mugti H, Aloraini MS, Alkhaldi KZ, Almohammadi EL, Alraddadi BM, Gerber SI and Swerdlow DL (2015) 2014 MERS-CoV outbreak in Jeddah - A link to health care facilities. N Engl J Med 372:846-854.

https://doi.org/10.1056/NEJMoa1408636

Ong SWX, Tan YK, Chia PY, Lee TH, Ng OT, Wong MSY and Marimuthu K (2020) Air, surface environmental, and personal protective equipment contamination by severe acute respiratory syndrome Coronavirus 2 (SARS-CoV-2) from a Symptomatic Patient. JAMA - J Am Med Assoc 323:28-30. 
https://doi.org/10.1001/jama.2020.3227

Ooi GC, Khong PL, Müller NL, Yiu WC, Zhou LJ, Ho JC, Lam B, Nicolaou S and Tsang KW (2004) Severe acute respiratory syndrome: temporal lung changes at thin-section CT in 30 patients. Radiology 230:836844. https://doi.org/10.1148/radiol.2303030853

Park JE, Li K, Barlan A, Fehr AR, Perlman S, McCray PB and Gallagher T (2016) Proteolytic processing of middle east respiratory syndrome coronavirus spikes expand virus tropism. Proc Natl Acad Sci U S A 113:12262-12267.

https://doi.org/10.1073/pnas.1608147113

Paterlini M (2020) On the front lines of coronavirus: the Italian response to covid-19. BMJ 368:m1065. https://doi.org/10.1136/bmj.m1065

Perlman S, Netland J (2009) Coronaviruses post-SARS: Update on replication and pathogenesis. Nat. Rev. Microbiol. 7:439-450

Qiu H, Wu J, Hong L, Luo Y, Song Q and Chen D (2020) Clinical and epidemiological features of 36 children with coronavirus disease 2019 (COVID-19) in Zhejiang, China: An observational cohort study. Lancet Infect Dis 20:1-8.

https://doi.org/https://doi.org/10.1016/S14733099(20)301 98-5.

Ren LL, Wang YM, Wu ZQ, Xiang ZC, Guo L, Xu T, Jiang YZ, Xiong Y, Li YJ, Li XW and Li H (2020) Identification of a novel coronavirus causing severe pneumonia in human. Chin Med J (Engl) 1 . https://doi.org/10.1097/cm9.0000000000000722

Sajadi MM, Habibzadeh P, Vintzileos A, Shokouhi S, Miralles-Wilhelm F and Amoroso A (2020) Temperature Wa and latitude analysis to predict potential spread and seasonality for COVID-19. SSRN 3550308.

Shereen MA, Khan S, Kazmi A, Bashir N and Siddique R (2020) COVID-19 infection: Origin, transmission, and characteristics of human coronaviruses. J Adv Res 24:91-98.

Sheridan C (2020) Fast, portable tests come online to curb coronavirus pandemic. Nat Biotech 10.

https://doi.org/10.1038/d41587-020-00010-2

Shi H, Han X, Jiang N, Cao Y, Alwalid O, Gu J, Fan Y and Zheng C (2020) Radiological findings from 81 patients with COVID-19 pneumonia in Wuhan, China: a descriptive study. Lancet Infect Dis 3099:1-10. https://doi.org/10.1016/S1473-3099(20)30086-4

Singhal T (2020) A Review of Coronavirus Disease-2019 (COVID-19). Indian J. Pediatr. 87:281

Stephen M and Hahn MD (2020) Coronavirus (COVID19) Update: Serological Tests FDA.

https://www.fda.gov/newsevents/pressannouncements/ coronavirus-covid-19-update-serological-tests.

Sundell N, Dotevall L, Sansone M, Andersson M, Lindh M, Wahlberg T, Tyrberg T, Westin J, Liljeqvist J $\AA$,
Bergström T andStudahl M (2017) Outbreaks Measles outbreak in Gothenburg urban area. Euro Surveill 24(17):1900114.

https://doi.org/10.2807/15607917.ES.2019.24.17.1900 114

Taubenberger JK and Morens DM (2006) 1918 Influenza: The mother of all pandemics. Emerg. Infect Dis 12:1522.

Taubenberger JK, Reid AH and Fanning TG (2000) The 1918 influenza virus: A killer comes into view. Virology 274:241-245. https://doi.org/10.1006/viro.2000.0495

Tyrrell DAJ and Bynoe ML (1965) Cultivation of a novel type of common cold virus in organ culture. Br Med $r$ 1:1467-70.

Qamar MT, Alqahtani SM, Alamri MA and Chen LL (2020) Structural basis of SARS-CoV-2 3CL pro and anti-COVID-19 drug discovery from medicinal plants. J Pharm Anal 1-26.

https://doi.org/10.20944/preprints202002.0193.v1

Vincent MJ, Bergeron E, Benjannet S, Erickson BR, Rollin PE, Ksiazek TG, Seidah NG and Nichol ST (2005) Chloroquine is a potent inhibitor of SARS coronavirus infection and spread. Virol J 2:1-10. https://doi.org/10.1186/1743-422X-2-69

Viner R, Russell S, Croker H, Packer J, Ward J, Stansfield C, Mytton O and Booy R (2020) School Closure and Management Practices During Coronavirus Outbreaks Including COVID-19: A rapid narrative systematic review. SSRN Electron J 2019:1-8. https://doi.org/10.2139/ssrn.3556648

Walls AC, Park YJ, Tortorici MA, Wall A, McGuire AT and Veesler D (2020) Structure, function, and antigenicity of the SARS-CoV-2 Spike Glycoprotein. Cell 181:281-292.e6.

https://doi.org/10.1016/j.cell.2020.02.058

Wang Y and Zhu LQ (2020) Pharmaceutical care recommendations for antiviral treatments in children with coronavirus disease 2019. World J Pediatr 20-23. https://doi.org/10.1007/s12519-020-00353-5

Wang M, Cao R, Zhang L, Yang X, Liu J, Xu M, Shi Z, $\mathrm{Hu} \mathrm{Z}$ andZhong W XG (2020) Remdesivir and chloroquine effectively inhibit the recently emerged novel coronavirus $(2019-\mathrm{nCoV})$ in vitro. Cell Res 30:269-271. https://doi.org/10.1038/s41422-020-02820

World Health Organization (2020) Coronavirus disease 2019 (COVID-19): situation report, 7.

World Health Organization (2020) Democratic Republic of the Congo EBOLA VIRUS DISEASE.

Williams AE and Chambers RC (2014) The mercurial nature of neutrophils: Still an enigma in ARDS? Am. J. Physiol. - Lung Cell. Mol. Physiol 306(3):L217-30.

Wilson N, Kvalsvig A, Barnard LT and Baker MG (2020) 
Case-Fatality Risk Estimates for COVID-19 Calculated by using a lag time for fatality. Emerg Infect Dis 26(6):1339. https://doi.org/10.3201/eid2606.200320

World Health Organization (2020) World Health Organization Covid 19 Infection. Available online: https://www.who.int/emergencies/diseases/ novel coronavirus-2019.

Wrapp D, Wang N, Corbett KS, Goldsmith JA, Hsieh CL, Abiona O, Graham BS and McLellan JS (2020a) CryoEM structure of the 2019-nCoV spike in the prefusion conformation. Science 367(80):1260-1263. https://doi.org/10.1126/science.aax0902

Wrapp D, Wang N, Corbett KS, Goldsmith JA, Hsieh CL, Abiona O, Graham BS and McLellan JS (2020b) CryoEM structure of the 2019-nCoV spike in the prefusion conformation. Science 367(80):1260-1263. https://doi.org/10.1126/science.abb2507

Wu C, Chen X, Cai Y, Zhou X, Xu S, Huang H, Zhang L, Zhou X, Du C, Zhang Y and Song J (2020) Risk factors associated with acute respiratory distress syndrome and death in patients with Coronavirus disease 2019 pneumonia in Wuhan, China. JAMA Intern Med 1-10. https://doi.org/10.1001/jamainternmed.2020.0994

Xie X, Zhong Z, Zhao W, Zheng $\mathrm{C}$, Wang $\mathrm{F}$ and Liu J. (2020) Chest CT for typical 2019-nCoV pneumonia: relationship to negative RT-PCR testing. Radiology 12:200343. https://doi.org/10.1148/radiol.2020200343

$\mathrm{Xu}$ Z, Shi L, Wang Y, Zhang J, Huang L, Zhang C, Liu S, Zhao P, Liu H, Zhu L and Tai Y (2020) Pathological findings of COVID-19 associated with acute respiratory distress syndrome. The Lancet respiratory medicine 8(4):420-2.

Yan Y, Zou Z, Sun Y, Li X, Xu KF, Wei Y, Jin N and Jiang C (2013) Anti-malaria drug chloroquine is highly effective in treating avian influenza A $\mathrm{H} 5 \mathrm{~N} 1$ virus infection in an animal model. Cell Res 23:300-302. https://doi.org/10.1038/cr.2012.165

Zhang L and Liu Y (2020) Potential interventions for novel coronavirus in China: A systematic review. J Med Virol 92:479-490.

https://doi.org/10.1002/jmv.25707

Zhao S, Lin Q, Ran J, Musa SS, Yang G, Wang W, Lou Y, Gao D, Yang L, He D and Wang MH (2020) Preliminary estimation of the basic reproduction number of novel coronavirus (2019-nCoV) in China, from 2019 to 2020: A data-driven analysis in the early phase of the outbreak. Int J Infect Dis 92:214-217. https://doi.org/10.1016/j.ijid.2020.01.050

Zhao S, Stone L, Gao D, He D (2018) Modelling the large-scale yellow fever outbreak in Luanda, Angola, and the impact of vaccination. PLoS neglected tropical diseases 12(1): $\mathrm{e} 0006158$.

https://doi.org/10.1371/journal.pntd.0006158
Zhou D, Dai SM and Tong Q (2020) COVID-19: a recommendation to examine the effect of hydroxychloroquine in preventing infection and progression. J Antimicrob Chemother 4-7.

https://doi.org/10.1093/jac/dkaa114

Zhou F, Yu T, Du R, Fan G, Liu Y, Liu Z, Xiang J, Wang Y, Song B, Gu X and Guan L (2020) Clinical course and risk factors for mortality of adult inpatients with COVID-19 in Wuhan, China: a retrospective cohort study. Lancet 6736:1-9. https://doi.org/10.1016/S0140-6736(20)30566-3

Zhou P, Yang XL, Wang XG, Hu B, Zhang L, Zhang W, Si HR, Zhu Y, Li B, Huang CL and Chen HD (2020) A pneumonia outbreak associated with a new coronavirus of probable bat origin. Nature 579:270-273. https://doi.org/10.1038/s41586-020-2012-7.

Zipprich J, Winter K, Hacker J, Xia D andWatt J HK (2015) Measles outbreak - California, MMWR. Morbidity and mortality weekly report 64(6): 153 .

Report of the WHO-China Joint Mission on Coronavirus Disease 2019 (COVID-19) - World Health Organization, Feb. 28, 2020.

https://www.worldometers.info/coronavirus/coronavirusdeath-rate/\#ref-12

What is Smallpox? Smallpox CDC. https://www.cdc.gov/smallpox/about/index.html.

Moss WJ and Griffin DE (2006) Global measles elimination. Nature Reviews Microbiology. 4(12):9008. https://doi.org/10.1038/nrmicro1550

Yellow fever (2008) In: WHO. Detect. Investig. serious Advers. events Follow. yellow fever vaccination, Geneva, World Heal. Organ.https://www.who.int/news-room/factsheets/detail/yellow-fever. 